\title{
ANAEROBIC CAPACITY OF SAILORS WITH DISABILITIES
}

\author{
GRZEGORZ PROKOPOWICZ1, BARTOSZ MOLIK², KATARZYNA PROKOPOWICZ1, \\ ANNA OGONOWSKA-SŁODOWNIK², JUDIT LENCSE-MUCHA², \\ NATALIA MORGULEC-ADAMOWICZ², ANDRZEJ KOSMOL ${ }^{2}$, KRZYSZTOF PERKOWSKI ${ }^{3}$, \\ TOMASZ CHAMERA ${ }^{4}$, TOMASZ GRZYWACZ ${ }^{5}$ \\ IJózef Rusiecki Olsztyn University College, Faculty of Physiotherapy \\ 2 Józef Pitsudski University of Physical Education in Warsaw, Faculty of Rehabilitation, \\ Chair of Movement Teaching \\ 3 Józef Pitsudski University of Physical Education in Warsaw, Faculty of Physical Education, Chair of Sport \\ ${ }^{4}$ Gdansk University of Physical Education and Sport, Faculty of Physical Education, Chair of Sport \\ Institute of Sport - National Research Institute in Warsaw, Department of Physiology
}

Mailing address: Katarzyna Prokopowicz, Józef Rusiecki Olsztyn University College, 33 Bydgoska Street, 10-243 Olsztyn, tel.: +48 514500105, fax: +48 89 5260400, e-mail: kprokopowicz@onet.eu

\begin{abstract}
Introduction. A review of Polish and international literature does not give a clear indication of the level of anaerobic capacity that sailors with disabilities demonstrate with regard to their functional capacities. This study sought to determine differences in functional capacity levels between sailors from three medical and functional groups. Material and methods. The research was carried out during a sports camp at the National Sailing Centre in Górki Zachodnie in 2014. Eighteen males with locomotor disabilities were included in the study. The athletes were members of the National Team of Sailors with Disabilities of the Polish Yachting Association. The sportsmen competed in the Skud 18 and 2.4mR Paralympic classes. A 30-second Wingate test for upper limbs was employed in the study. Results. Significant differences in mean power (MP) values were noted between the groups under investigation. The group of wheelchair sailors with improper core stability (A) and the group of wheelchair sailors with proper core stability (B) had significantly lower scores than the group of study participants who were able to move freely, that is to walk (C). Conclusions. The study revealed that a 30 -second anaerobic capacity test performed on an arm ergometer differentiated disabled sailors from selected groups in terms of mean power. Research on anaerobic capacity may be used to verify the current classification in Paralympic sailing and will make it possible to differentiate present competition categories.
\end{abstract}

Key words: Paralympic sailing, Wingate test, national team

\section{Introduction}

Sailing is one of the newest Paralympic sports. As a demonstration sport, it was first introduced at the Atlanta 1996 Paralympic Games. Four years later in Sydney, sailors were able to compete in two categories, that is in the three-person Sonar and two-person 2.4mR races. Since the Beijing 2008 Paralympic Games, they have also been able to participate in two-person Skud 18 competitions [1-2]. Paralympic sailing creates excellent opportunities for disabled athletes' all-round development. Moreover, it helps to develop their personality traits and to increase their physical capacity [3-7]. Owing to its comprehensive impact, participation in training sessions significantly improves their health and mood, and it may replace a number of therapies [3-4].

Anaerobic capacity parameters in sailors with disabilities make it possible to carry out an initial analysis regarding their physical capacity to take part in training sessions and competitions. Because it is often necessary to perform quick and dynamic repetitive movements while executing complex manoeuvres on a boat (such as tacking or jibing as well as pulling the gennaker up and down), anaerobic performance seems to be significant when trying to achieve high results. During a competition, one sailing race usually lasts for $60-75$ minutes. Within this time, sailors perform the above-mentioned tasks several dozen times.

No reports concerning the anaerobic capacity of sailors with disabilities can be found in either the Polish or international literature regarding the subject. Accordingly, their levels of anaerobic capacity with regard to their functional capacities cannot be determined. Therefore, it is necessary to conduct research aimed at assessing the physical performance of individuals with disabilities who practise sailing. The findings may contribute to the selection of optimal training methods and may exert considerable influence on the development of Paralympic sailing. This study sought to determine differences in functional capacity levels between sailors from three medical and functional groups.

\section{Material and methods}

The research was conducted on 18 males with locomotor disabilities (paraplegia, amputations of lower limbs, and congenital limb deficiencies). The competitors were members of the 2014 National Team of Sailors with Disabilities of the Polish Yachting Association. They competed in the Skud 18 and $2.4 \mathrm{mR}$ classes. On average, they were 46.3 years old, with a body height of $175.1 \mathrm{~cm}$ (measurement accuracy of $\pm 0.5 \mathrm{~cm}$ ) and body mass 
of $78.6 \mathrm{~kg}$ (measurement accuracy of $\pm 0.1 \mathrm{~kg}$ ). The subjects were divided into three groups according to their functional capacities and movement patterns:

A - wheelchair sailors with improper core stability,

B - wheelchair sailors with proper core stability,

C - sailors with minimal disabilities (able to walk).

This classification was first used by Molik in the analysis of the anaerobic capacity of athletes with locomotor dysfunctions who participated in various sports [8]. It is a modification of the medical classification developed by Hutzler et al. [9].

The group examined consisted of 6 wheelchair sailors with improper core stability (A), 4 wheelchair sailors with proper core stability (B), and 8 sailors who could move without wheelchairs $(C)$. Their mean training experience was $12.3 \pm 5.6$ years. The majority of sailors did not practise regularly, especially in off-season. Only two athletes took up activity other than sailing (hand biking and paragliding). Prior to the commencement of the study, an approval was obtained from the Senate Research Ethics Committee of the Józef Piłsudski University of Physical Education in Warsaw. All participants were informed about the study procedure and study aim and about the possibility of withdrawing at any time. All of them gave their written consent to participating in the study.

The research was carried out in May 2014 during a sports camp at the National Sailing Centre in Górki Zachodnie. A 30-second Wingate test was employed to assess the anaerobic capacity of sailors with disabilities. It is a standard test used to examine individuals with various types of disabilities [8-14]. Since the same tool was applied in all cases, it is possible to compare the findings with results obtained in other sports and with reference values. The procedure of testing anaerobic capacity was the same for all athletes and consisted of three parts: a warm-up, a 30-second Wingate test, and a rest period. The Wingate test was performed on a LODE ANGIO arm ergometer (Groningen, Netherlands) with the software package Wingate v.1.07b (Groningen, Netherlands). The height of the device was individually adjusted to each participant in a sitting position so that the rotation axis of the ergometer was at the level of the shoulder joint. Furthermore, the wheelchair was stabilised by two assistants during the examination. Prior to the test of anaerobic capacity, the sailors performed a 2-minute warm-up with 60 rotations per minute and a load of $50 \mathrm{~W}$. During the main part of the test, the sailors were asked to perform as many ergometer rotations as possible with an individually adjusted load in 30 seconds. The load for the participants from groups A and $\mathrm{B}$ constituted $3.5 \%$ of their body mass, whereas in the case of group C, it was $4.5 \%$ of the body mass. During the test, the athletes were verbally encouraged to do their best.

During the Wingate test, mean power (MP) and peak power (PP) were measured. Also, fatigue index (FI), defined as a decrease in power from PP level to the lowest power value, was calculated. The index was automatically calculated because the software package Wingate v.1.07b (Groningen, Netherlands) was connected to the arm ergometer. Moreover, relative mean power (rMP) and relative peak power (rPP), determined with regard to the participants' body mass, were calculated.

Statistical analysis was carried out using IBM SPSS Statistics 23 software for Microsoft Windows. Normality of distribution was assessed with the Kolmogorov-Smirnov test. The nonparametric Kruskal-Wallis test was applied to determine the significance of differences between groups A, B, and C, while the non-parametric U Mann-Whitney test was employed to assess the significance of differences between pairs of the groups. Statistical significance was set at $\mathrm{p}<0.05$.

\section{Results}

A general description of the sailors in the groups is shown in Table 1 . The analysis did not reveal any significant differences between the groups in terms of age, body height, body mass, or training experience. The analysis of physical capacity parameters showed significant differences in MP between sailors from group $\mathrm{C}$ and other groups. The subjects from groups $\mathrm{A}$ and $\mathrm{B}$ obtained significantly lower values than those from group $C$. The study participants from group A scored $248.6 \pm 41.3$ pts [W], the subjects from group B scored $251.5 \pm 58.2$ pts [W], while the participants from group C obtained $339.6 \pm 57.2$ pts [W] (tab. 2).

The analysis of the Wingate test results did not reveal any significant differences between the groups in terms of PP, rMP, rPP, or FI (tab. 2).

Table 1. Description of the sailors with disabilities (mean values and standard deviations)

\begin{tabular}{|c|c|c|c|c|}
\hline Group & Age [years] & $\begin{array}{c}\text { Body height } \\
{[\mathbf{c m}]}\end{array}$ & $\begin{array}{c}\text { Body mass } \\
{[\mathrm{kg}]}\end{array}$ & $\begin{array}{c}\text { Training experi- } \\
\text { ence [years] }\end{array}$ \\
\hline $\mathbf{A}(\mathbf{n}=\mathbf{6})$ & $47.6 \pm 9.1$ & $174.3 \pm 4.9$ & $76.6 \pm 11.6$ & $14.5 \pm 3.4$ \\
\hline $\mathbf{B}(\mathbf{n}=\mathbf{4})$ & $41.0 \pm 12.6$ & $171.2 \pm 4.4$ & $73.2 \pm 12.9$ & $12.5 \pm 6.2$ \\
\hline $\mathbf{C}(\mathbf{n}=\mathbf{8})$ & $48.0 \pm 5.9$ & $177.6 \pm 6.6$ & $81.5 \pm 12.8$ & $13.3 \pm 5.1$ \\
\hline Total & $46.3 \pm 8.7$ & $175.1 \pm 5.9$ & $78.0 \pm 12.2$ & $12.3 \pm 5.6$ \\
\hline
\end{tabular}

$\mathrm{A}=$ wheelchair sailors with improper core stability, $\mathrm{B}$ = wheelchair sailors with proper core stability, $\mathrm{C}=$ sailors with minimal disabilities (able to walk).

Table 2. Anaerobic capacity test results of the sailors with disabilities in selected medical and functional groups (mean values and standard deviations)

\begin{tabular}{|c|c|c|c|c|c|}
\hline Group & $\begin{array}{c}\text { MP } \\
{[W]}\end{array}$ & $\begin{array}{c}\text { PP } \\
{[W]}\end{array}$ & $\begin{array}{c}\text { rMP } \\
{[W / k g]}\end{array}$ & $\begin{array}{c}\text { rPP } \\
{[W / k g]}\end{array}$ & $\begin{array}{c}\text { FI } \\
{[W / s e c .]}\end{array}$ \\
\hline A & $248.6 \pm 41.3$ & $363.8 \pm 90.4$ & $3.3 \pm 0.6$ & $4.7 \pm 1.2$ & $8.8 \pm 3.9$ \\
\hline B & $251.5 \pm 58.5$ & $357.7 \pm 78.1$ & $3.4 \pm 0.8$ & $4.8 \pm 0.7$ & $7.6 \pm 2.6$ \\
\hline C & $339.6 \pm 57.2^{*}$ & $499.6 \pm 113.7$ & $4.1 \pm 0.4$ & $6.0 \pm 0.9$ & $11.5 \pm 3.1$ \\
\hline Total & $289.7 \pm 67.5$ & $422.8 \pm 117.5$ & $3.7 \pm 0.7$ & $5.3 \pm 1.1$ & $9.7 \pm 3.5$ \\
\hline
\end{tabular}

$\mathrm{MP}=$ mean power $\mathrm{PP}=$ peak power; $\mathrm{rMP}=$ relative mean power; $\mathrm{rPP}=$ relative peak power; $\mathrm{FI}=$ fatigue index; * $=\mathrm{p}<0.05$ for $\mathrm{C}$ vs. $\mathrm{A}$ and $\mathrm{C}$ vs. $\mathrm{B}$; $\mathrm{A}=$ wheelchair sailors with improper core stability; $\mathrm{B}=$ wheelchair sailors with proper core stability; $\mathrm{C}=$ sailors with minimal disabilities (able to walk).

\section{Discussion}

The anaerobic capacity of athletes with disabilities has often been the subject of scientific research over the years [8-17]. The selection of a homogenous group (different types of disabilities and sports for the disabled) as well as small sample size are crucial problems regarding the standardisation of results and the definition of standards for anaerobic capacity. It is necessary to conduct research on anaerobic capacity among athletes with disabilities for a number of reasons. These include the need to verify the system of the functional classification of athletes, the professionalisation of sport for the disabled, as well as the inves- 
tigation of the correlation between anaerobic capacity and types of locomotor dysfunctions [8, 10-15, 17-20].

There is a paucity of data on issues related to sailors with disabilities. To date, research has mainly focused on analysing selected aspects of recreational sailing, taking into account the needs and functional capacities of individuals with disabilities, economic and socio-cultural aspects, as well as factors that encouraged them to take up sailing [21-25]. This seems to stem from the fact that this discipline has been present at the Paralympic Games for a short time [1-2, 26]. The findings regarding MP are in line with the results obtained in other sports practised by the disabled. Differences in selected anaerobic capacity parameters between athletes from various disability groups have already been described in the literature [8-14, 16-19, 27]. The classification in wheelchair basketball was assessed with the use of the anaerobic capacity test by Molik et al. [10]. In their research, they found differences between players with minimal functional limitations and those using wheelchairs in everyday life. Also, Van der Woude et al. [27] noted correlations between the levels of PP. Furthermore, studies related to anaerobic capacity were conducted on wheelchair rugby and basketball players as well as para-canoeists. They revealed that athletes with the most limited functional capacities (the highest disability level) differed from others in terms of anaerobic parameters [8, 10-13].

Sailors from group $\mathrm{C}$ demonstrated higher functional capacities, which is linked to the fact that they obtained higher MP values in the Wingate test on the arm ergometer. Taking into account the classification system in sport for the disabled, the division of sailors with disabilities into functional capacity classes seems to be justified. Significant differences in MP exhibited by the sailors with disabilities may result from the specificity of sailing, the position on a boat (a crew member or a helmsman), and the execution of particular manoeuvres on a boat. These differences may be seen as evidence confirming the assumption that in sailing, anaerobic capacity plays a crucial role for people with disabilities, especially under strong wind conditions. Other authors made similar observations while studying the anaerobic capacity of able-bodied sailors in the Laser class [28]. The lack of differences between the groups in the other parameters examined (PP, rMP, rPP, and FI) may be connected with imprecise training cycles that depended on the place of living and the sailors' involvement in training between camps.

While comparing the results obtained by sailors with disabilities to reference values of anaerobic capacity (MP, PP, rMP, and $\mathrm{rPP}$ ) in the 30-second Wingate test performed in the group of disabled males practising sport, we noted that the sailors under investigation demonstrated different levels in their scores. The scale of reference values consisted of 7 grading levels: very bad, bad, below average, average, good, very good, and excellent. Moreover, three age categories were analysed: 18-25 years, 26-35 years, and over 35 years [13]. The sailors examined belonged to the oldest age group. Athletes from group A manifested an average level of MP and PP and a good level of rMP and rPP. Sailors from group B demonstrated scores below average in MP, rMP, and rPP and had a bad level of PP. Athletes from group C displayed an average level of MP, PP, rMP, and rPP.

Further research on sailing for people with disabilities ought to focus on determining objective possibilities of assessing athletes with the most accurate parameters. Due to the specificity of the performance of sailors with disabilities, it is worth looking for new specific tests that would verify anaerobic capacity levels. Even though it seems that athletes' sailing skills and their yachting knowledge are the main success factors in regattas, their physical capacity may prove significant as well [29-30]. Using capacity and strength parameters in verifying the classification system of sailors with disabilities also appears to be essential.

\section{Conclusions}

The study allowed us to confirm that a 30-second test of anaerobic capacity performed on an arm ergometer differentiated disabled sailors from selected groups in terms of mean power. Research on anaerobic capacity may be used to verify the current classification in Paralympic sailing and will make it possible to differentiate selected competition classes. It is advisable to carry out further research that takes into consideration all 7 classes according to the IFDS (International Association for Disabled Sailing) classification and with regard to the sailor's function on a boat (helmsman, crew member).

\section{Acknowledgements}

The study was conducted as part of the research carried out by Józef Rusiecki Olsztyn University College and Józef Piłsudski University of Physical Education in Warsaw (DS. 162) financed by the Ministry of Science and Higher Education.

\section{Literature}

1. Neville V., Folland J.P. (2009). The epidemiology and etiology of injuries in sailing. Sports Medicine 39(2), 129-145. DOI: 10.2165/00007256-200939020-00003.

2. Paralympic.org. Updated July 03, 2016. Retrieved July 05, 2016, from https://www.paralympic.org/results/historical.

3. Neuhorn S., Lasotka M. (2002). Sailing possibilities in individuals with locomotor disabilities. Wychowanie Fizyczne i Sport 46 (Suppl. 1), 213-214. [in Polish]

4. Piskorz C., Klimek-Piskorz E. (2000). Educational and therapeutic values of sailing for individuals with disabilities. Wychowanie Fizyczne i Sport 44, 101-108. [in Polish]

5. Stańkowska K., Błacha R. (2000). Sailing as a form of health training. Medycyna Sportowa 111, 25-27. [in Polish]

6. Szczygieł A., Klimek E. (1989). Sailing for individuals with disabilities - selected issues. Zeszyty Naukowe AWF Kraków 59, 63-70. [in Polish]

7. Kochanowicz K., Prusik K. (2002). The impact of sailing on balance system functioning among sailors. Rocznik Naukowy AWF Gdańsk 11, 257-264. [in Polish]

8. Molik B., Laskin J.J., Kosmol A., Skucas K., Bida U. (2010). Relationship between functional classification levels and anaerobic performance of wheelchair basketball athletes. Research Quarterly for Exercise and Sport 81(1), 69-73. DOI: 10.1080/02701367.2010.10599629.

9. Hutzler Y. (1998). Anaerobic fitness testing of wheelchair users. Sports Medicine 25(2), 101-113.

10. Molik B., Laskin J.J., Kosmol A., Marszałek J., MorgulecAdamowicz N., Frick T. (2013). Relationships between anaerobic performance, field tests, and functional level of elite female wheelchair basketball athletes. Human Movement 14(4), 366-371. DOI: 10.2478/humo-2013-0045.

11. Starczewski M., Molik B. (2014). Selected anaerobic capacity parameters with regard to paracanoe functional classification. Postępy Rehabilitacji 28(1), 31-35. DOI: 10.2478/ rehab-2014-0031. [in Polish]

12. Morgulec-Adamowicz N., Kosmol A., Molik B., Yilla A.B., Laskin J.J. (2011). Aerobic, anaerobic, and skill performance with regard to classification in wheelchair rugby athletes. 
Research Quarterly for Exercise and Sport 82(1), 61-9. DOI: 10.1080/02701367.2011.10599722.

13. Molik B. (2010). Anaerobic performance and efficiency in team games versus classification of athletes with disabilities. Warszawa: AWF Warszawa. [in Polish]

14. De Lira C.A.B., Vancini R.L., Minozzo F.C., Sousa B.S., Dubas J.P., Andrade M.S. et al. (2010). Relationship between aerobic and anaerobic parameters and functional classification in wheelchair basketball players. Scandinavian Journal of Medicine E Science in Sports 20, 638-643. DOI: 10.1111/j.1600-0838.2009.00934.x.

15. Goosey-Tolfrey V. (2010). Wheelchair sport. A complete guide for athletes, coaches and teachers. Champaign, IL: Human Kinetics.

16. Hutzler Y. (2000). Anaerobic performance of older female and male wheelchair basketball players on a mobile wheelchair ergometer. Adapted Physical Activity Quarterly 17, 450-465.

17. Vanlandewijck Y.C., Daly D., Theisen D. (1999). Field test evaluation of aerobic, anaerobic, and wheelchair basketball skill performances. International Journal of Sports Medicine 20, 548-554. DOI: 10.1055/s-1999-9465.

18. Jacobs P.L., Mahoney E.T., Johnson B. (2003). Reliability of arm Wingate anaerobic testing in persons with complete paraplegia. The Journal of Spinal Cord Medicine 26(2), 141144.

19. Molik B., Kosmol A., Morgulec N., Hubner-Woźniak E., Rutkowska I. (2006). Anaerobic performance in Polish First League Team of Wheelchair Basketball Players. Research Yearbook - Studies in Physical Education and Sport 12(2), 199-202.

20. Vanlandewijck Y.C., Spaepen A.J., Lysens R.J. (1994). Wheelchair propulsion: Functional ability dependent factors in wheelchair basketball players. Scandinavian Journal of Rehabilitation Medicine 26, 37-48.

21. Zamelska M., Kaczor B. (2008). Needs and opportunities for the development of tourism for individuals with disabilities based on the experience of the Department of Tourism and Recreation of the University School of Physical Education in Poznań. In A. Stasiak, J. Śledzińska (eds), The role of sightseeing and tourism in the lives of persons with disabilities (pp. 147-156). Warszawa: Wyd. PTTK „Kraj”. [in Polish]

22. Czupryna-Nowak A., Hysa B., Jankowska-Suwalska K., Mularczyk A., Szromek A.R. (2011). Analysis of selected aspects of tourism taking into account the needs of individuals with disabilities. Zeszyty Naukowe Politechniki Ślaskiej Seria: Organizacja i zarzadzanie 57, 1847. [in Polish]

23. Kuźmicki M., Dąbrowski D. (2011). The economic situation as a determinant of the tourist activity of individuals with disabilities. Zeszyty Naukowe Szkoły Gtównej Gospodarstwa Wiejskiego, Ekonomika i Organizacja Gospodarki Żywnościowej 93, 159-169. [in Polish]

24. Prokopowicz G., Molik B., Prokopowicz K., Chamera T., Ogonowska-Słodownik A., Lencse-Mucha J. et al. (2016). Motives for participation in Paralympic sailing - opinions of Polish and international athletes with physical disabilities. Postępy Rehabilitacji 30(3), 17-26.

25. Wiliński W. (2010). Stereotypes in Paralympic sports as a socio-cultural condition of health. Problemy Higieny $i$ Epidemiologii 91(2), 298-302. [in Polish]

26. Allen J.B., De Jong M.R. (2006). Sailing and sports medicine: A literature review. British Journal of Sports Medicine 40(7), 587-93. DOI: 10.1136/bjsm.2002.001669.

27. Van der Woude L.H., Bakker W.H., Elkhuizen J.W., Veeger H.E., Gwinn T. (1997). Anaerobic work capacity in elite wheelchair athletes. American Journal of Physical Medicine E Rehabilitation 76(5), 355-65.

28. Larsson B., Beyer N., Bay P., Blond L., Aagaard P., Kjaer M. (1996). Exercise performance in elite male and female sailors. International Journal of Sports Medicine 17(7), 504508.

29. Chamera T. (2007). The structure of the final preparation period and its effects on sport results of sailors taking part in the 2004 Olympic Games. Studies in Physical Culture and Tourism 14(Suppl.), 241-247.

30. Suchanowski A., Jastrzębski Z., Jaszczur-Nowicki J. (2006). Physiological characteristics of sailing in the light of the research results of the best Polish sailors: Research in 19772003. Gdańsk: Wyd. AWFiS Gdańsk. [in Polish]

Submitted: November 4, 2016

Accepted: February 14, 2017 